\title{
Mites (Acari: Trombidiformes) parasitizing mosquitoes (Diptera: Culicidae) in an Atlantic Forest area in southern Brazil with a new mite genus country record
}

\author{
Emili Bortolon dos $\operatorname{Santos}^{1} \cdot$ Mario Arthur Favretto ${ }^{2} \cdot$ \\ Samuel Geremias dos Santos $\operatorname{Costa}^{3,4} \cdot$ Mario Antonio Navarro-Silva ${ }^{1}$
}

Received: 14 December 2015/Accepted: 8 April 2016/Published online: 16 April 2016

(C) Springer International Publishing Switzerland 2016

\begin{abstract}
In this study, a total of 4146 culicids collected in an Atlantic Forest area in Paraná state, southern Brazil were examined for the presence of mites. Forty larval Parasitengone mites (Arrenurus spp., Arrenuridae; Durenia spp., Trombellidae; Microtrombidium spp., Microtrombidiidae) parasitized 25 specimens of mosquitoes, with the intensity varying from one to nine mites attached. Most mites were found on Aedes serratus/nubilus, Culex vomerifer, $C x$. pedroi and $C x$. sacchettae. The overall percentage of parasitized mosquitoes was $0.6 \%$. The highest intensity of mites encountered was in an individual of $C x$. pedroi with nine attached mites. Regarding the attachment site, most mite specimens were attached to the abdomen $(\mathrm{n}=25)$, whereas 15 were located on the thorax. Specimens of Arrenurus spp. were only found on the abdomen of mosquitoes, and the same was observed for Microtrombidium spp., while Durenia spp. attached to both the thorax $(\mathrm{n}=15)$ and abdomen $(\mathrm{n}=4)$. This is the first record for the genus Durenia in Brazil. Additionally, some species of mosquitoes were, for the first time, reported as being parasitized by mites.
\end{abstract}

Keywords Arrenurus $\cdot$ Brazil $\cdot$ Culicidae $\cdot$ Durenia $\cdot$ Microtrombidium

Emili Bortolon dos Santos

emilibortolon@hotmail.com; emili.bsantos@gmail.com

1 Post-graduation Program in Entomology, Federal University of Paraná, Curitiba, Paraná State 81531-980, Brazil

2 Post-graduation Program in Ecology and Conservation, Federal University of Paraná, Curitiba, Paraná State 81531-980, Brazil

3 Federal University of Minas Gerais, Belo Horizonte, Minas Gerais State 31270-901, Brazil

4 Museum of Biological Diversity, Ohio State University, Columbus, OH, USA 


\section{Introduction}

The parasitism of Parasitengona mites on insects is common, usually observed in aquatic mites for insects that have at least one life stage in the water, but also occur on other taxa. Among the insect hosts, Diptera (Culicomorpha) is one of the main groups that is parasitized by water mites (Smith and Oliver 1986). Regarding the culicids, Arrenurus spp. and Parathyas barbigera are the taxa best known for parasitizing a large number of mosquito species (Di Sabatino et al. 2000).

DeGeer made the first record of a culicid parasitized by mites, at the time describing the mite species Trombidium culicis (Mullen 1975). Back then, the culicids were not well studied, as people did not know their role in the transmission of agents causing diseases in humans and other animals. In 1876, Patrick Manson discovered that mosquitoes could spread nematode worms responsible for causing filariasis. This was the first time that the relationship between insects and disease transmission was established (Eldrige 1992).

Nowadays, it is known that culicids can spread several etiological agents. Besides filariasis, they can also transmit dengue, chikungunya, zika virus, yellow fever, encephalitis and malaria, among others diseases. The last disease is responsible for about 198 million cases each year and more than 580 thousand deaths per year (Fang 2010; WHO 2015). Given the importance of this group of insects for public health, it is logical to search for potential biological agents for these vectors. Many studies indicate that mites impose negative impacts on mosquitoes, because they reduce the life expectancy and reproductive capacity (Lanciani and Boyt 1977; Smith and McIver 1984a; Snell and Heath 2006).

Mites belonging to the sub-order Parasitengona have a life cycle including three active instars, a larva that is parasitic of various arthropod species including Diptera, heteromorphic deutonymphs and adults that are free-living predators, interspersed with inactive, non-motile instars (Welbourn 1983; Smith 1988; Wohltmann 2000).

The mites that parasitize mosquitoes are mainly aquatic and need to feed in order to reach the deutonymphal stage. Later, as adults, they commonly act as predators of insects eggs and larvae (Esteva et al. 2007). After the appearance of the host adult stage, the mite becomes a parasite and remains with the insect until its return to the water for reproduction or oviposition. The mites can also detach from the hosts on land (Di Sabatino et al. 2000). Terrestrial Parasitengona mites, e.g. Microtrombidium spp. (Microtrombidiidae), can attach to mosquitoes that have the immature stages in the accumulated water in the soil, such as Aedes serratus, which may develop in temporary puddles and less frequently in permanent breeding sites (Forattini 2002).

The studies with mites parasitizing mosquitoes are concentrated in some countries, such as the USA (Tsai et al. 1969; Spurrier 1998; Kirkhoff et al. 2013), Pakistan (Reisen and Mullen 1978), Germany (Werblow et al. 2015), Australia (Williams and Proctor 2002) and New Zealand (Snell and Heath 2006). Meanwhile, studies with mites in Brazil, in their majority, are concentrated in species descriptions, associating the specimens to the parasitized organism (e.g. Treat and Flechtmann 1979; Haitlinger 1987, 2004). In this country, the studies about mites' parasitism in mosquitoes are scarce, not having systematic surveys, restricted to the study of Flechtmann (1974), where there was a record of a mosquito species being parasitized by several mites. In addition, Mullen (1975) made some records of mosquitoes being parasitized by unidentified mites in Brazil.

In this context, taking into account the importance of increasing knowledge regarding the interaction mite-Culicidae in the Neotropical region, the aim of this study was to 
conduct a research on the species of mosquitoes that are parasitized by mites in an Atlantic Forest fragment in the state of Paraná, in southern Brazil.

\section{Methods}

Mosquitoes and mites were collected in an Atlantic Forest area, in the Floresta Estadual do Palmito, located in the municipality of Paranaguá, in Paraná state, in the South of Brazil $\left(25^{\circ} 35^{\prime} \mathrm{S}, 48^{\circ} 32^{\prime} \mathrm{W}\right)$. The area has 530 ha of native vegetation and is a conservation park of sustainable use (Fig. 1). It is bordered by PR-407 Road in the south, by Cotinga's Canal (Paranaguá Bay) in the north, by the Almeidas' River in the east and by Ribeirão das Correias in the west.

The studied area is characterized as having Cfa subtropical climate. The average temperature in the coldest months is about $18{ }^{\circ} \mathrm{C}$ and in the warmest months is about $22{ }^{\circ} \mathrm{C}$. Frosts are infrequent and the summer is usually warm and rainy, there is no welldefined dry season, according to the Köeppen classification (Iapar 2010). The annual average precipitation is about $1950 \mathrm{~mm}$ and the rainiest months are January and February, however, there is rain distribution throughout the year, which makes the place very humid; the average relative air humidity in a year is $85 \%$ (Boeger and Wisniewski 2003).

The vegetation of the area is classified as Dense Ombrophilous Forest of Low Lands, however, the area has vegetation with influence from the sea (sandbank), it has mangrove areas and areas modified by humans. In Floresta Estadual do Palmito the forest formation is composed by individuals that can reach more than $20 \mathrm{~m}$ high.

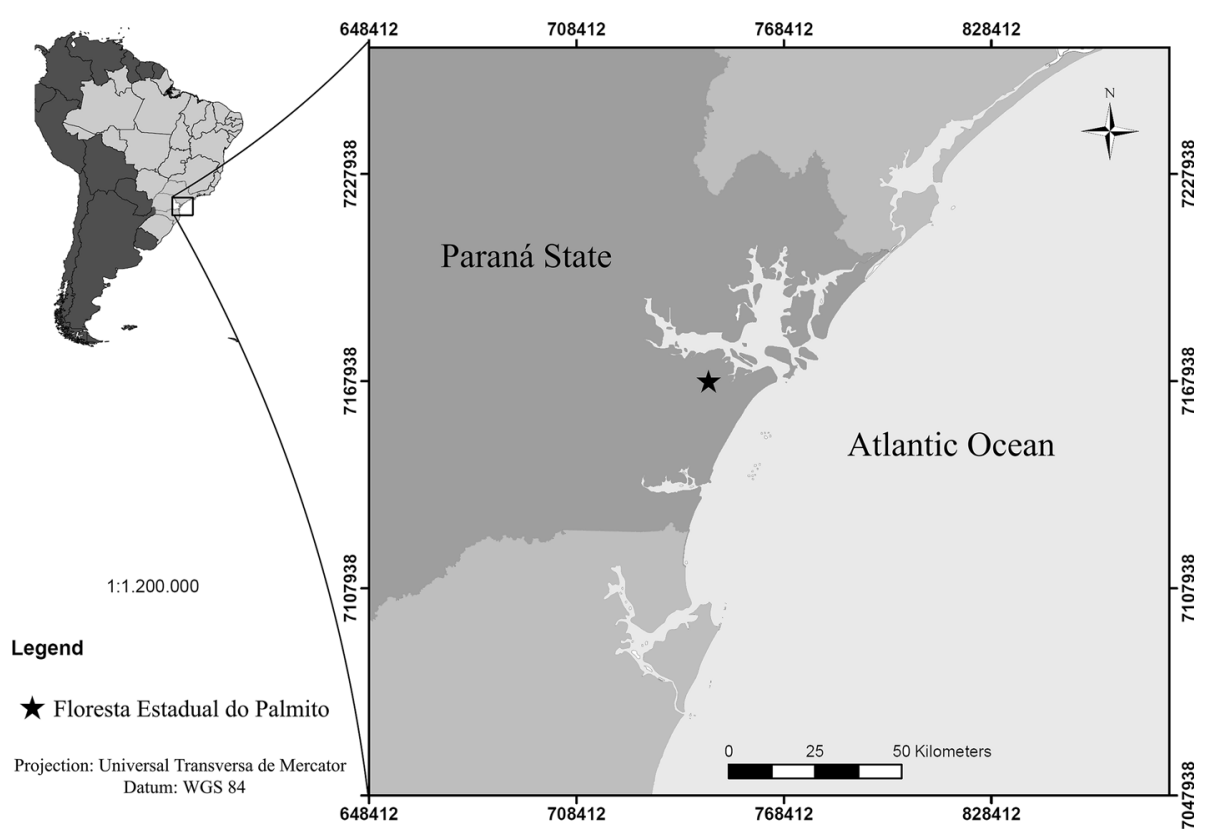

Fig. 1 Location of Floresta Estadual do Palmito, Paranaguá, Paraná state, Brazil, where the collections were performed 
Regarding the collections of culicids, they were performed between June 2014 and May 2015, with the exception of July and August 2014. Mosquitoes were collected with the Nasci aspirator, searching for the insects in the middle of low vegetation. After collections, culicids were stored in a freezer until sorting. In the sorting, parasitized mosquitoes were separated from non-parasitized ones. The attachment site in the mosquito's body was divided in two categories: abdomen and thorax. They were identified with help of dichotomous keys from Rozeboom and Komp (1950), Galindo et al. (1954), Consoli and Oliveira (1994), Sallum and Forattini (1996) and Forattini (2002). We followed the abbreviation system of Culicidae genera and subgenera accordingly to Reinert (2009). The specimens are deposited in the Coleção Entomológica Padre Jesus Santiago Moure at the Federal University of Paraná, Curitiba, in the state of Paraná.

The mites were mounted using Hoyer's medium, which was prepared according to the protocol described by Krantz and Walter (2009), then kept in the stove at $50{ }^{\circ} \mathrm{C}$ for four days to dry, in the third day the borders were cleaned and after the fourth day the slides were sealed with glaze. Mites were identified with keys to family from Krantz and Walter (2009) and Mullen (1974). The genera were identified using the keys from Southcott (1994) and Saboori et al. (2003, 2005). Three mite genera are illustrated by photos (Fig. 2) taken with the Nikon Eclipse 90i compound microscope equipped with a Nikon DS-fi1 camera and Adobe Illustrator imaging software. The specimens were deposited for future consultation in the Taxonomic Collection of the Laboratory of Systematics and Evolution of Acariform Mites, with the codes: UFMG-AC (1301053-1301060 and 1301062-1301095), at the Federal University of Minas Gerais, Belo Horizonte, in the state of Minas Gerais.

\section{Results}

Of the 4146 specimens of Culicidae collected, 1639 mosquitoes were identified and divided into nine genera and 42 species. From these, 25 individuals were parasitized by mites, 19 females and six males (Table 1). The taxon with the highest parasitism index was Ae. serratus/nubilus, which corresponded to $28 \%(\mathrm{n}=7)$ of the total of parasitized mosquitoes, followed by Culex vomerifer $(16 \% ; \mathrm{n}=4)$, Culex pedroi and Culex sacchettae, both representing $12 \%(\mathrm{n}=3)$. Forty mites in total were found attached to the mosquitoes, ranging from one to nine mites attached to each, represented by the genera Arrenurus (47.5\%; $\mathrm{n}=19)$, Durenia (47.5\%; $\mathrm{n}=19)$ and Microtrombidium (5\%; $\mathrm{n}=2$ ).

Overall, the percentage of infestation for mites was $0.6 \%$ throughout the collection period. Aedes serratus/nubilus and Ae. hortator were only parasitized by the genus $A r-$ renurus. Culex vomerifer was parasitized by one Arrenurus larva and three Durenia larvae. Culex pedroi was also parasitized by Arrenurus and Durenia, as well as $C x$. sacchettae. We collected two specimens of Uranotaenia mathesoni, both were parasitized.

Culex pedroi was the species with the largest number of mites attached $(n=11)$, being that one specimen was parasitized by nine mites, six Durenia and three Arrenurus. Culex vomerifer was parasitized by eight mites, two specimens were parasitized with three Durenia mites each. Aedes serratus/nubilus specimens had eight attached mites, however, only one had two Arrenurus mites attached, the others had only one mite each.

In this study we observed mites being attached more to the mosquitoes' abdomen $(\mathrm{n}=25)$, and less frequently to the thorax $(\mathrm{n}=15)$. The genus Arrenurus only parasitized 

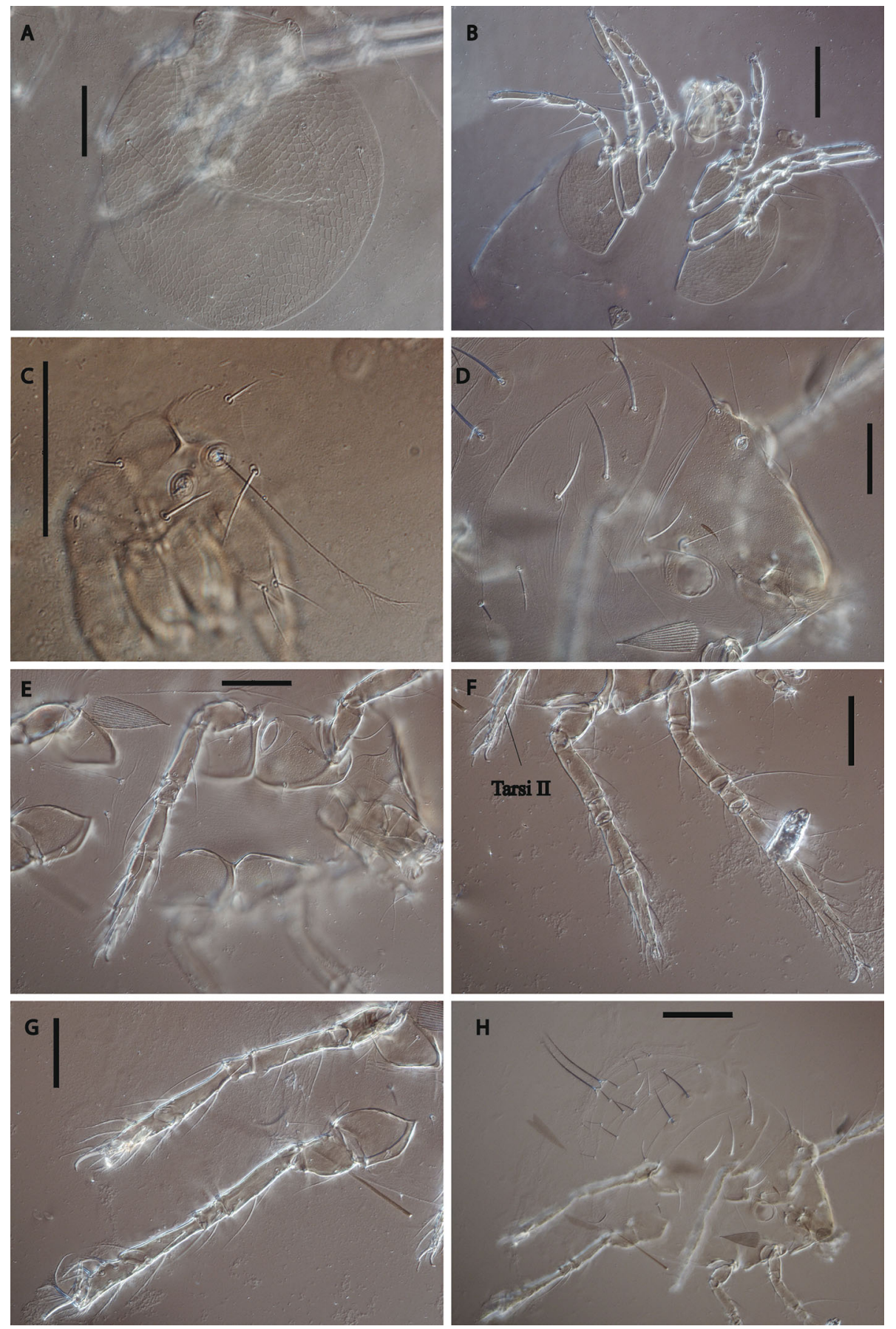

Fig. 2 Arrenurus sp. (a) Scutum; (b) Ventral view. Durenia sp. (c) Scutum. Microtrombidium sp. (d) Scutum; (e) Ventral view; (f) Leg I and II; (g) Leg III; (h) General view. Scale a, b, h: $100 \mu \mathrm{m}$; c-g: $50 \mu \mathrm{m}$ 
Table 1 Parasitized mosquitoes collected in an Atlantic Forest area in southern Brazil

\begin{tabular}{|c|c|c|c|c|c|}
\hline \multirow[t]{2}{*}{ Culicidae species } & \multirow{2}{*}{$\begin{array}{l}\text { Total no. } \\
\text { mosquitoes }\end{array}$} & \multirow{2}{*}{$\begin{array}{l}\text { No. parasitized } \\
\text { mosquitoes }\end{array}$} & \multicolumn{3}{|l|}{ Mite abundance } \\
\hline & & & Microtrombidium & Arrenurus & Durenia \\
\hline Anopheles cruzii & 138 & 0 & 0 & 0 & 0 \\
\hline Aedes fulvus & 1 & 0 & 0 & 0 & 0 \\
\hline Aedes oligopistus & 1 & 0 & 0 & 0 & 0 \\
\hline Aedes scapularis & 32 & 0 & 0 & 0 & 0 \\
\hline Aedes serratus & 17 & 0 & 0 & 0 & 0 \\
\hline Aedes serratus/nubilus & 443 & $7 q$ & 0 & 7 & 0 \\
\hline Aedes hortator & 89 & 19 & 0 & 1 & 0 \\
\hline Psorophora ferox & 197 & 0 & 0 & 0 & 0 \\
\hline Culex bidens & 1 & 0 & 0 & 0 & 0 \\
\hline Culex declarator & 4 & 0 & 0 & 0 & 0 \\
\hline Culex lygrus & 1 & 0 & 0 & 0 & 0 \\
\hline Culex mollis & 71 & 0 & 0 & 0 & 0 \\
\hline Culex neglectus & 1 & 0 & 0 & 0 & 0 \\
\hline Culex nigripalpus & 75 & 0 & 0 & 0 & 0 \\
\hline Culex dunni & 1 & 0 & 0 & 0 & 0 \\
\hline Culex pedroi & 4 & $3 q$ & 0 & 1 & 2 \\
\hline Culex pedroi/ribeirensis & 2 & 0 & 0 & 0 & 0 \\
\hline Culex pilosus & 3 & 0 & 0 & 0 & 0 \\
\hline Culex sacchettae & 81 & $2+1 \jmath$ & 0 & 1 & 2 \\
\hline Culex spissipes & 8 & 0 & 0 & 0 & 0 \\
\hline Culex vomerifer & 4 & $4 \widehat{\jmath}$ & 0 & 1 & 3 \\
\hline Culex zeteki & 2 & 1 운 & 0 & 1 & 0 \\
\hline Culex aphylactus & 3 & 0 & 0 & 0 & 0 \\
\hline Culex imitator & 8 & $1+$ & 1 & 0 & 0 \\
\hline Culex (Microculex) spp. & 31 & 1 우 & 1 & 0 & 0 \\
\hline Limatus durhamii & 41 & 0 & 0 & 0 & 0 \\
\hline Runchomyia reversa & 95 & 0 & 0 & 0 & 0 \\
\hline Trichoprosopon pallidiventer & 1 & 0 & 0 & 0 & 0 \\
\hline Wyeomyia leucostigma & 19 & 0 & 0 & 0 & 0 \\
\hline Wyeomyia sabethea & 1 & 0 & 0 & 0 & 0 \\
\hline Wyeomyia davisi & 12 & 0 & 0 & 0 & 0 \\
\hline Wyeomyia edwardsi & 1 & 0 & 0 & 0 & 0 \\
\hline Wyeomyia fuscipes & 1 & 0 & 0 & 0 & 0 \\
\hline Wyeomyia pallidoventer & 106 & 0 & 0 & 0 & 0 \\
\hline Wyeomyia quasilongirostris & 1 & 0 & 0 & 0 & 0 \\
\hline Wyeomyia theobaldi & 3 & 0 & 0 & 0 & 0 \\
\hline Wyeomyia cf. lassali & 120 & 0 & 0 & 0 & 0 \\
\hline Wyeomyia confusa & 1 & 0 & 0 & 0 & 0 \\
\hline Wyeomyia coenonus/tarsata & 44 & 0 & 0 & 0 & 0 \\
\hline Wyeomyia shannoni & 1 & 0 & 0 & 0 & 0 \\
\hline Uranotaenia mathesoni & 2 & $2+$ & 0 & 2 & 0 \\
\hline
\end{tabular}


Table 1 continued

\begin{tabular}{|c|c|c|c|c|c|}
\hline \multirow[t]{2}{*}{ Culicidae species } & \multirow{2}{*}{$\begin{array}{l}\text { Total no. } \\
\text { mosquitoes }\end{array}$} & \multirow{2}{*}{$\begin{array}{l}\text { No. parasitized } \\
\text { mosquitoes }\end{array}$} & \multicolumn{3}{|l|}{ Mite abundance } \\
\hline & & & Microtrombidium & Arrenurus & Durenia \\
\hline Uranotaenia pallidoventer & 2 & 0 & 0 & 0 & 0 \\
\hline Uranotaenia spp. & 62 & $1+1$, $1 \hat{}$ & 0 & 1 & 1 \\
\hline
\end{tabular}

mosquitoes' abdomen $(\mathrm{n}=19)$, none was found on the thorax. The same was observed for Microtrombidium spp. On the other hand, most Durenia spp. were attached to the thorax $(\mathrm{n}=15)$, although some were found on the abdomen $(\mathrm{n}=4)$. Specimens of Ae. serratus/ nubilus only were parasitized by mites on the abdomen $(\mathrm{n}=8)$, the same was observed for Ae. hortator $(\mathrm{n}=2)$. Culex pedroi had three Arrenurus mites attached to the abdomen and seven Durenia attached to the thorax and one to the abdomen. A similar pattern was observed for $C x$. vomerifer, which had one Arrenurus mite attached to the abdomen and six Durenia to the thorax and one to the abdomen (Table 2).

\section{Discussion}

There are just a few studies on mites parasitizing mosquitoes in Brazil. We can cite Flechtmann (1974), a study where one specimen of Culex fatigans (synonym: Cx. quinquefasciatus) was found parasitized by 15 Arrenurus mites. We did not find other related studies, thus, our study is probably the first to do a systematic investigation on mosquitoes being parasitized by mites in Brazil. The overall percentage of parasitized mosquitoes in the period from June 2014 to May 2015 was $0.6 \%$. Kirkhoff et al. (2013) collected 929,873 mosquitoes in Pennsylvania, USA, among them, $0.2 \%$ were parasitized by mosquitoes $(\mathrm{n}=1836)$. A similar pattern was observed in Australia, where from 19,280 mosquitoes collected, $0.3 \%$ were parasitized by mites (Williams and Proctor 2002). On the other hand, there are studies where the percentage is higher, such as in Ontario, Canada (6.7\%) (Smith and McIver 1984b) and in another study, also in Ontario, Smith and McIver (1984a) found a much higher percentage: $87.5 \%$.

This variation of percentage of parasitism in different countries may be related to the species composition of the studied areas and fresh water availability for the presence of mosquitoes (Milne et al. 2008). Some abiotic factors may strongly influence the distribution and abundance of mosquitoes. Rainfall, for instance, can alter the abundance and type of breeding sites for mosquitoes (Shaman and Day 2007), thus, according to the climate of a certain region, some species of mosquitoes can vary their development. That is, each region of the planet has its own Culicidae fauna, which can also vary during the year due the climate.

We collected 25 parasitized mosquitoes, of these, 19 were composed by females, while only six were males. Mites apparently attach more in the females because after they become adults they return to the water to lay their eggs. In many dipterans species only the female return to the water for oviposition, so if the mites attach males, their life cycles could not be completed (Mullen 1974; Smith and McIver 1984a; Lanciani 1988; Rolff 2001).

Mites were most often found on the abdomen of the mosquitoes in this study. Snell and Heath (2006) also found mites attached mainly to the abdomen, and in lower numbers on the thorax and on the legs as well. Milne et al. (2008) generally observed aquatic mites attached 
Table 2 Attachment sites of each mite genus on the parasitized mosquitoes collected in an Atlantic Forest area in southern Brazil

\begin{tabular}{|c|c|c|c|c|c|c|c|}
\hline \multirow[t]{2}{*}{ Culicidae species } & \multicolumn{2}{|c|}{ Microtrombidium } & \multicolumn{2}{|l|}{ Arrenurus } & \multicolumn{2}{|l|}{ Durenia } & \multirow[t]{2}{*}{ Total } \\
\hline & Abdomen & Thorax & Abdomen & Thorax & Abdomen & Thorax & \\
\hline Ae. serratus/nubilus & 0 & 0 & 8 & 0 & 0 & 0 & 8 \\
\hline Ae. hortator & 0 & 0 & 2 & 0 & 0 & 0 & 2 \\
\hline$C x$. imitator & 1 & 0 & 0 & 0 & 0 & 0 & 1 \\
\hline Cx. pedroi & 0 & 0 & 3 & 0 & 1 & 7 & 11 \\
\hline Cx. sacchettae & 0 & 0 & 1 & 0 & 1 & 2 & 4 \\
\hline$C x$. vomerifer & 0 & 0 & 1 & 0 & 1 & 6 & 8 \\
\hline Cx. zeteki & 0 & 0 & 1 & 0 & 0 & 0 & 1 \\
\hline$C x .(M c x$.$) sp.$ & 1 & 0 & 0 & 0 & 0 & 0 & 1 \\
\hline Ur. mathesoni & 0 & 0 & 2 & 0 & 0 & 0 & 2 \\
\hline Ur. (Ura.) sp. & 0 & 0 & 1 & 0 & 1 & 0 & 2 \\
\hline Total & 2 & 0 & 19 & 0 & 4 & 15 & 40 \\
\hline
\end{tabular}

to the abdomen of mosquitoes, the same was found in this study, where Arrenurus, an aquatic mite, only parasitized the abdomen. Mitchell (1959) in a study on Arrenurus demonstrated that the site each species of mite chose to attach to was directly related to the way that the Odonata species laid their eggs. We emphasize that the total amount of parasitized mosquitoes was low, so inferences about host and attachment site preferences are premature.

We found that Arrenurus was the genus which parasitized the greatest diversity of mosquitoes. This probably occurred due this genus's biology, as it lives in different types of freshwater environments, allowing it to encounter different host species (Mlynarek et al. 2015). Arrenurus is the genus most reported parasitizing mosquitoes, whose activity had already been documented in several countries, reinforcing its flexibility regarding the hosts. There are several species of Arrenurus mites which may parasitize these insects (Tsai et al. 1969; Reisen and Mullen 1978; Williams and Proctor 2002; Morales and Miranda 2008; Werblow et al. 2015).

All species of mosquitoes collected in this study were found being parasitized by Arrenurus, with the exception of species of the subgenera Microculex. This can be an indication that this genus perhaps is not developing in bromeliads, which is the common container in which Microculex is found (Lourenço-de-Oliveira et al. 1986). This is confirmed by the other species collected in this study which were not parasitized and may develop in bromeliads, such as Anopheles cruzii and Wyeomyia (Phoniomyia) (Consoli and Oliveira 1994; Forattini 2002).

Regarding the other species parasitized by Arrenurus collected in this study, Ae. serratus specimens have their immature stages developing mainly in temporary puddles in the soil, formed by rain. The same is true for the other collected species of Culex, belonging to the subgenera Melanoconion. Aedes hortator can develop in stone holes and also in temporary puddles in the soil (Forattini 1965, 2002; Hutchings et al. 2002). Immature stages of Uranotaenia species develop in swamps among aquatic vegetation (Galindo et al. 1954). Therefore, in this study Arrenurus was only found parasitizing mosquitoes which have a life phase in the soil, demonstrating a distribution pattern, as was observed by Williams and Proctor (2002) in South Australia. 
Microtrombidium was collected in only two mosquitoes, $C x$. imitator and an unidentified species of Culex (Microculex). The immature stages of these mosquitoes can develop in natural containers such as tree holes and bromeliads, especially the ones located on stones and in the soil (Kumm 1933; Lourenço-de-Oliveira et al. 1986). In contrast to the majority of mites which parasitize mosquitoes, Microtrombidium mites live in the soil. They have been reported parasitizing Culicidae (e.g. Michener 1946) and it is understandable that mosquitoes who can develop in bromeliads located in the soil, for instance, can be attached by larval mites on land.

Regarding the genus Durenia, little information is known, there is one study about its relation as parasites of mosquitoes (Mullen 1975). Despite the reduced number, almost half of all mites parasitizing mosquitoes in the present study belonged to Durenia, which could indicate that this genus could be easily found parasitizing Culicidae, at least in Brazil. However, a major quantity of information about the relation Durenia-Culicidae is necessary, mainly because here we present the first record of this genus in Brazil.

Mites probably carry out a natural control of mosquitoes and a lot of other insect taxa as well. Besides reducing life expectancy and egg reproduction, mites are known for delaying sexual maturity and reducing the flight capability. In all cases, the impact of parasitism depends on the quantity of parasites attached to the insects and can also affect the whole population of a certain species (Smith et al. 2001). García et al. (1994) observed the parasitism by mites in natural populations of Culicidae and conclude that the prevalence and number of mites in each host were low.

We emphasize here that we made the first records of some species of mosquitoes being parasitized by mites: Ae. hortator, Cx. imitator, Cx. pedroi, Cx. sacchettae, Cx. zeteki and Ur. mathesoni. In addition, based on a literature search, this is the first record of the genus Durenia for Brazil. We also found some specimens new to science; the description process is underway. It is evident that the studied area needs to be better explored in order to improve knowledge regarding mites parasitizing mosquitoes in this country.

Acknowledgments The authors want to thank CNPq (Conselho Nacional de Desenvolvimento Científico e Tecnológico) and CAPES (Coordenação de Aperfeiçoamento de Pessoal de Nível Superior) for the grants to EBS, MAF and SGSC, this last with the government program "Ciência sem Fronteiras". Our special thanks to Aristides Fernandes, from School of Public Health, University of São Paulo, for the identification of some Culicidae species. We are grateful to Hans Komplen from Ohio State University and Warren C. Welbourn, from University of Florida, for their valuable contribution for the improvement of this study. We also want to thank to the reviewers who contributed to the improvement of this manuscript as well.

\section{References}

Boeger MRT, Wisniewski C (2003) Comparison of leaf morphology of tree species from three distinct successional stages of tropical rain forest (Atlantic Forest) in Southern Brazil. Rev Bras Bot 1:61-72

Consoli RAGB, Oliveira RL (1994) Principais mosquitos de importância sanitária no Brasil. Fiocruz, Rio de Janeiro

Di Sabatino A, Gerecke R, Martin P (2000) The biology and ecology of lotic water mites (Hydrachnidia). Freshwater Biol 44:47-62

Eldrige BF (1992) Patrick Manson and the discovery age of vector biology. J Am Mosq Control Assoc 8:215-220

Esteva L, Rivas G, Yang HM (2007) Assessing the effects of parasitism and predation by water mites on the mosquitoes. Trends Appl Comput Math 8:63-72

Fang J (2010) A world without mosquitoes. Nature 466:432-434

Flechtmann CHW (1974) Caso de um mosquito intensamente parasitado por larvas de ácaros aquáticos. Anais da Escola Superior de Agricultura Luiz de Queiroz 31:361-366 
Forattini OP (1965) Entomologia Médica. Faculdade de Saúde Pública, USP, São Paulo

Forattini OP (2002) Culicidologia Médica: Identificação, biologia, epidemiologia. EDUSP, São Paulo

Galindo P, Blanton FS, Peyton EL (1954) A revision of the Uranotaenia of Panama with notes on other American species of the genus. Ann Entomol Soc Am 47:107-177

García JJ, Campos RE, Maciá A (1994) Prospeccion de enemigos naturales de Culicidae (Diptera) de la selva marginal de Punta Lara (Prov. de Buenos Aires, Republica Argentina). Rev Acad Colomb Cienc 19:209-216

Haitlinger R (1987) Leptus stolae sp. n. (Acari, Prostigmata, Erythraeidae) from Stolas nudicollis (Boh.) (Coleoptera, Chrysomelidae, Cassidinae) from Brazil. Pol Pis Entomol 57:357-359

Haitlinger R (2004) Charletonia domawiti n. sp., Caeculisoma nestori n. sp., and Iguatonia barbillae n. gen. and n. sp. from Brazil (Acari: Prostigmata: Erythraeidae). Genus 15:435-444

Hutchings RSG, Sallum MAM, Ferreira RLM (2002) Culicidae (Diptera: Culicomorpha) da Amazônia Ocidental Brasileira: Querari. Acta Amaz 32(109):122

Iapar-Instituto Agronômico do Paraná (2010) Cartas climáticas do Paraná. http://www.iapar.br/modules/ conteudo/conteudo.php?conteudo=677. Accessed 19 April 2015

Kirkhoff CJ, Simmons TW, Hutchinson M (2013) Adults mosquitoes parasitized by larval water mites in Pennsylvania. J Parasitol 99:31-39

Krantz GW, Walter DE (eds) (2009) A manual of Acarology. Texas Tech University Press, Texas

Kumm HW (1933) Mosquitoes breeding in bromeliads, at Bahia, Brazil. Bull Entomol Res 24:561-573

Lanciani CA (1988) Sexual bias in host selection by parasitic mites of the mosquito Anopheles crucians (Diptera: Culicidae). J Parasitol 74:768-773

Lanciani CA, Boyt AD (1977) The effect of a parasitic water mite, Arrenurus pseudotenuicollis (Acari: Hydrachnellae), on the survival and reproduction of the mosquito Anopheles crucians (Diptera: Culicidae). J Med Entomol 14:10-15

Lourenço-de-Oliveira R, Heyden R, Silva TF (1986) Alguns aspectos da ecologia dos mosquitos (Diptera, Culicidae) de uma área de planície (Granjas Calábria), em Jacarepaguá, Rio de Janeiro. V. Criadouros. Mem Inst Oswaldo Cruz 81:265-271

Michener CD (1946) The taxonomy and bionomics of some panamanian trombidiidae mites (acarina). Ann Entomol Soc Am 39:349-380

Milne MA, Townsend-Jr VJ, Smelser P, Felgenhauer BE, Moore MK, Smytih FJ (2008) Larval aquatic and terrestrial mites infesting a temperate assemblage of mosquitoes. Exp Appl Acarol 47(19):33

Mitchell R (1959) Life histories and larval behavior of Arrenurid water-mites parasitizing Odonata. J N Y Entomol Soc 67:1-12

Mlynarek JJ, Knee W, Smith BP, Forbes MR (2015) Regionally widespread parasitic water mites have relatively broad host-species ranges. Can J Zool 93:1-6

Morales J, Miranda R (2008) Coquillettidia venezuelensis Theobald (Diptera: Culicidae) parasitados por larvas de Arrenurus Dugés (Acari: Prostigmata: Arrenuridae) en el Caribe Central de Panamá. Rev Nica Ent 68:1-7

Mullen GL (1974) Acarine parasites of mosquitoes. II. Illustrated larval key to the families and genera of mites reportedly parasitic on mosquitoes. Mosq News 34:183-195

Mullen GL (1975) Acarine parasites of mosquitoes. I. A critical review of all known records of mosquitoes parasitized by mites. J Med Entomol 12:27-36

Reinert JF (2009) List of abbreviations for currently valid genetic-level taxa in family Culicidae (Diptera). Eur Mosq Bull 27:68-76

Reisen WK, Mullen GR (1978) Ecological observations on acarine associates (Acari) of Pakistan mosquitoes (Diptera: Culicidae). Environ Entomol 7:769-776

Rolff J (2001) Evolutionary ecology of water mite-insect interactions: a critical appraisal. Arch Hydrobiol 152:353-368

Rozeboom LE, Komp WHW (1950) A review of the species of Culex of the subgenus Melanoconion (Diptera: Culicidae). Ann Entomol Soc Am 43:75-114

Saboori A, Hajiqanbar H, Irani-Nejad KH (2003) A new genus and species of mite (Acari: Trombidiidae) ectoparasitic on thrips in Iran. Int J Acarol 29:127-132

Saboori A, Nemati A, Mossahebi G (2005) A new genus and species of Trombellidae (Acari: Trombidioidea) from Iran. Int J Acarol 31:45-50

Sallum MAM, Forattini PO (1996) Review of the Spissipes section of Culex (Melanoconion). J Am Mosq Control Assoc 12:517-600

Shaman J, Day JF (2007) Reproductive phase locking of mosquito populations in response to rainfall frequency. PLoS ONE 2:e331

Smith BP (1988) Host parasite interaction and impact of larval water mites on insects. Ann Rev Entomol 33:487-507 
Smith BP, McIver SB (1984a) The impact of Arrenurus danbyensis Mullen (Acari: Prostigmata: Arrenuridae) on a population of Coquillettidia perturbans (Walker) (Diptera: Culicidae). Can J Zool 62:1121-1134

Smith BP, McIver SB (1984b) The patterns of mosquito emergence (Diptera: Culicidae; Aedes spp.): their influence on host selection by parasitic mites (Acari: Arrenuridae; Arrenurus spp.). Can J Zool 62:1106-1113

Smith IM, Oliver DR (1986) Review of parasitic associations of larval water mites (Acari: Parasitengona: Hydrachnida) with insect hosts. Can Entomol 118:407-472

Smith IM, Cook DR, Smith BP (2001) Water mites (Hydrachnida) and other arachnids. In: Thorp JH, Covich AP (eds) Ecology and classification of North American freshwater invertebrates. Academic Press, San Diego, pp 551-659

Snell AE, Heath ACG (2006) Parasitism of mosquitoes (Diptera: Culicidae) by larvae of Arrenuridae and Microtrombidiidae (Acari: Parasitengona) in the Wellington region, New Zealand. New Zeal J Zool 33:9-15

Southcott RV (1994) Revision of the larvae of the Microtrombidiinae (Acarina: Microtrombidiidae) with notes on life histories. Zoologica 48:1-155

Spurrier MF (1998) Mite parasitism of mosquitoes in Central Wyoming. Great Basin nat 58:184-187

Treat AE, Flechtmann CHW (1979) Charletonia rocciai sp. n. (Acari, Prostigmata, Erythraeidae), an ectoparasite of the amazon fly. Int J Acarol 5:117-122

Tsai YH, Grundmann AW, Rees DM (1969) Parasites of mosquitoes in Southwestern Wyoming and Northern Utah. Mosq News 29:102-110

Welbourn WC (1983) Potential use of trombidioid and erythraeoid mites as biological control agents of insect pests. In: Hoy MA, Cunningham GL; Knutson L (eds). Biological Control of Pests by Mites. Agricultural Experiment Station, Division of Agriculture and Natural Resources, University of California, Berkeley. Special Publication, 3304:103-140

Werblow A, Martin P, Dörge DD, Koch LK, Mehlhorn H, Melaun C, Klimpel S (2015) Hyperparasitism of mosquitoes by water mite larvae. Parasitol Res 114:2757-2765

WHO-World Health Organization (2015) Relatório sobre o paludismo no mundo. http://apps.who.int/iris/ bitstream/10665/160458/3/WHO_HTM_GMP_2015.2_por.pdf?ua=1\&ua=1. Accessed 11 Oct 2015

Williams CR, Proctor HC (2002) Parasitism of mosquitoes (Diptera: Culicidae) by larval mites (Acari: Parasitengona) in Adelaide, South Australia. Aust J Entomol 41:161-163

Wohltmann A (2000) The evolution of life histories in Parasitengona (Acari: Prostigmata). Acarologia 41:145-204 